\title{
VOLUNTARY ENVIRONMENTAL GOVERNANCE ARRANGEMENTS
}

\section{WORKING PAPER}

Accepted for publication in:

Environmental Politics, 21 (3), 486-509

\section{Authors}

Dr. Jeroen van der Heijden

Australian National University, Regulatory Institutions Network (RegNet)

University of Amsterdam, Amsterdam Law School

j.j.vanderheijden@anu.edu.au

www.jeroenvanderheijden.net

\begin{abstract}
Voluntary environmental governance arrangements (VEGAs) have focal attention in studies on environmental policy, regulation and governance. The four major debates in the contemporary literature on VEGAs are studied. It is found that the literature falls short of sufficiently specifying whether or not VEGAs are successful in addressing environmental risks. This is due to (i) the narrow focus of many contemporary studies; and (ii) a tendency in the literature to study the form and content of VEGAs in isolation from their contextual settings. In order to gain a better understanding of VEGAs, scholars are challenged to study differently structured VEGAs in different contextual settings; to move beyond single country or single VEGA studies; and, to combine quantitative and qualitative data in studying these arrangements.
\end{abstract}

\section{Key words}

governance, environment, regulation, voluntarism, beyond compliance 
Van der Heijden (2013) Voluntary environmental governance arrangements - page 2 of 17

\section{Voluntary environmental governance arrangements: a review*}

\section{Introduction}

In addressing environmental harms, governments, industries and non-governmental organizations (NGOs) are relying more and more on regulatory and governance arrangements that encourage firms to reduce their environmental impacts voluntarily to or beyond the requirements established by existing environmental legislation or comparable environmental goals (Nash and Ehrenfeld 1997, Segerson and Miceli 1998, Mol et al. 2000, Khanna and Anton 2002, Baranzini and Thalmann 2004, Weber and Hemmelskamp 2005, Lyon and Maxwell 2007, Darnall and Sides 2008, Potoski and Prakash 2009, Nel and Wessels 2010). The common features of these arrangements are a move away from traditional state-led regimes; the involvement of public and private sector stakeholders in rule making and rule implementation; more collaborative policy processes; and, governance instruments that are less rigid, less prescriptive, less committed to uniform outcomes, foster experimentation, and are less hierarchical in nature (De Búrca and Scott 2005, Armstrong and Kilpatrick 2007, Trubek and Trubek 2007a, Ansell and Gash 2008). Whilst some scholars and practitioners hold high expectations of these instruments' ability to address environmental harms, others express serious concerns and question the extent to which these voluntary environmental governance arrangements (VEGAs) are effective in improving their participants' environmental performance. In short, so contemporary literature argues, in some contexts VEGAs are effective, whilst in others they are not.

This review article addresses these conflicting findings and aims to map the four major debates on VEGAs in the literature. On the one hand, it aims to present an overview of the current knowledge of these arrangements and that which is yet understudied; on the other hand, it aims to better understand why many of the findings presented in the literature are conflicting in nature. A major cause of conflicting findings can be traced to the tendency in the literature to study the content and structure of these governance arrangements in isolation from their context and setting. From here, the article concludes by drawing some explicit implications for studying VEGAs.

\section{$2 \quad$ How voluntary are these arrangements, and how do they relate to state legislation?}

A major concern in the literature relates to the level of voluntarism of VEGAs (Segerson and Miceli 1998, Lyon and Maxwell 2007, Darnall and Sides 2008, Potoski and Prakash 2009). A purist would say that such arrangements can only be voluntary if there is no state involvement at all - either in a VEGA's development, or in its implementation. Contemporary literature takes a more realist point of view and finds that in current environmental policy practice many, if not most, of these arrangements are initiated or implemented with at least some form of state involvement (cf. Baranzini and Thalmann 2004, Potoski and Prakash 2009). Broadly speaking, three approaches are distinguished in the literature. First, VEGAs that are developed and implemented by state actors aiming to nudge or incentivize non-state actors to voluntarily improve their environmental performance (Darnall and Carmin 2005). Second, VEGAs that arise as an outcome of a collaborative state-industry policy-making process. In such cases non-state actors and state-regulators enter into agreements on these non-state actors' performances - for example, negotiated agreements or covenants (Freeman 1997, Mol et al. 2000, De Clercq 2002, Ansell and Gash 2008). Third, 'pure' voluntary VEGAs that are drawn up by firms and their industry associates without any state involvement (e.g. Cashore et al. 2004, Cooper and Symes 2009). As such, a strict focus on non-state 
involvement in these arrangements would exclude many existing examples or hypothetical constructs from analysis. This may limit the range of potential lessons for policy making on which we can draw, and limit the possibilities of testing and developing theories on VEGAs.

A second concern in the literature considers how VEGAs relate to existing environmental legislation (e.g. de Bruijn and Norberg-Bohm 2005, Trubek and Trubek 2007b, Cafaggi and Janczuk 2010). On the one hand, the literature questions whether and how existing state legislation and existing institutional settings allow the implementation of VEGAs. It considers existing legislation as push or pull factors for VEGAs to develop (Weber and Hemmelskamp 2005 - see also section 3 of this article), and considers existing institutions or country characteristics as providing both institutional space for and couleur locale to VEGAs (Mol et al. 2000, Orts and Deketelaere 2001, Morgenstern and Pizer 2007, Bressers et al. 2011) - which may partially explain why VEGAs are a more common policy tool in certain countries than others (EEA 1997). On the other hand, the literature addresses specific interactions between existing state legislation and VEGAs (Trubek and Trubek 2007b; also, Jordan et al. 2005, Van der Heijden 2011). State legislation is considered to be the 'lowest common denominator' that participants of a VEGA have to meet, and which may act as a 'safety net' or default that comes into play when the voluntary arrangement fails (De Búrca and Scott 2005). Specific interactions are studied. As alternatives, substitutes, or complements, VEGAs and state legislation exist side-by-side and may mutually reinforce each other. As rivals or competitors, VEGAs and state legislation again exist side-by-side, but do so in a more aggressive way. Competition may limit state and non-state actors' willingness to cooperate (Van der Heijden 2010); whereas under rivalry interaction the VEGA may ultimately replace state legislation, or vice versa (Trubek and Trubek 2007b). In such a case, the arrangement either becomes the 'new' legislation, or is abolished in favour of legislation. ${ }^{1}$ Alternatively, all forms of interaction may ultimately result in the merging or transformation of environmental legislation (see also, Trubek and Trubek 2007b, Van der Heijden 2011); for instance, when aspects of the VEGA are incorporated into state legislation.

\section{What are the rationales to develop VEGAs?}

Where the first debate in the literature has a strong focus on the dividing line between the public and the private spheres, and the actual meaning of the word 'voluntary', the second debate addresses the questions of why do non-state or state actors develop or join VEGAs? What are these actors' rationales in doing so? Whilst a strand of the literature is cynical and considers these actors as economic utility maximizers that only develop or join VEGAs when it serves their own interests (for rational choice theorizing, see Mueller 2003), other strands of the literature claim that many existing VEGAs cannot be explained form this point of view. In addition to rational choice theorizing, this literature also takes institutional, technological and behavioural factors into account (cf. Young 1999, Weber and Hemmelskamp 2005).

What brings the different strands of literature together is that they all address the exogenous or contextual conditions that affect the development and implementation of VEGAs. Four of such contextual conditions recur throughout the literature. Table 1 provides an overview of these conditions, the claims and hypotheses made in this literature related to these conditions, the studies that evidence these claims and hypotheses, and finally the literature that counterclaims or provides counterevidence to these claims and hypotheses. 
The impact of current or future state legislation is considered to be one of the major drivers for both state and non-state actors to develop VEGAs (Young 1994, Scott 2001, 2002, MacDonald and Richardson 2004, Schulz and Held 2004, Bernstein and Hannah 2008, Thatcher and Coen 2008, Dibden and Cocklin 2010). It is generally considered that non-state actors develop VEGAs to prevent the implementation of future or additional state legislation (Maxwell et al. 2000, Reid and Toffel 2009). State actors are considered to develop and implement VEGAs when they anticipate that future legislation is costly to implement and enforce, when they want to investigate or promote innovative policy ideas, or when political resistance exists for implementing more stringent legislation (Esty and Chertow 1997, Segerson and Miceli 1998, Delmas and Terlaak 2001, Darnall and Carmin 2005, Lyon and Maxwell 2007, Short and Toffel 2010).

Also, market conditions are considered a significant driver for the development of VEGAs. From a purely economic point of view the only logical rationale in developing or participating in a VEGA would be if the profit from participating outweighs the costs of participation (Howarth et al. 2000, Croci 2005). More demand driven motivation is found in the literature on 'green consumerism' and 'green investors'. Green consumerism implies consumers' demands for products that have better environmental performance than that required by governmental regulation, and a willingness to pay a premium for such products (Arora and Gangopadhyay 1995, Feddersen and Gilligan 2001, Florida and Davison 2001, Heyes and Maxwell 2004, Baron and Diermeier 2007). 'Green investors' implies investors' concerns with a firms' environmental performance (Hamilton 1995, Hoffman 2001, Graff Zivin and Small 2005), which 'could be viewed as exposing the firm to greater risks of liabilities, penalties and high costs of compliance in the future, or reflecting poor management practices and lack of innovativeness' (Khanna and Anton 2002, p. 543). A final argument from the literature on market conditions holds that non-state actors strive to guide state-regulators to tighten existing standards in their industry, aiming to hinder non-participating firms in that industry (Barrett 1991, Salop and Scheffman 1991).

Then, closely related to market conditions, societal pressures are considered to be drivers for state and non-state actors to develop and implement VEGAs (Den Hond and De Bakker 2007, Briscoe and Safford 2008, King 2008, Mikler 2009, Reid and Toffel 2009). On the one hand, the literature discusses direct and indirect action by NGOs - that is, addressing the board of a large firm, or mobilizing on a certain site to prevent a firm's operation (Bartly 2003, Baron and Diermeier 2007, King 2008), or influencing consumer behaviour through boycotts and negative information campaigns (Arora and Cason 1996, Bartly 2003, Baron and Diermeier 2007, King 2008). On the other hand, the literature discusses 'green worker' campaigns, where employees transpose their environmental concerns onto their employers (Lyon and Maxwell 2007, Brekke and Nyborg 2008, Briscoe and Safford 2008).

Finally, the literature addresses how sector and industry characteristics affect state and nonstate actors' willingness to develop or participate in VEGAs. It considers sectors or industries that are characterized by high levels of innovativeness or competition to be more likely to develop VEGAs than sectors or industries with low levels of innovativeness or competition (Arora and Cason 1996, Khanna and Anton 2002, Weber and Hemmelskamp 2005). It further considers that non-state actors who operate in an international setting are more likely to develop VEGAs (Bansal and Hunter 2003). Subsequently, this branch of literature addresses the capability of non-state actors to draw up rules and enforce these among participants as necessary for the development of VEGAs (Olson 1965, Rees 1988, Parker 2002, Baarsma et al. 2003, Potoski and Prakash 2009). It finally addresses issues related 
to the ease with which actors join a VEGA - that is, VEGAs with low entry barriers may attract more participants than VEGAs with high entry criteria (Potoski and Prakash 2009); or, actors with strong past environmental performance records may find it easier to join a VEGA than actors with poor past performance records (Bansal and Hunter 2003).

To conclude, the literature on the development and implementation of VEGAs provides a wide range of contextual conditions that are hypothesized to affect state and non-state actors' willingness to develop or participate in VEGAs. However, as Table 1 shows many hypotheses are presented, but not all are (yet) evidenced. Furthermore, as Table 1 illustrates, this literature also provides a range of counterclaims to these hypotheses, resulting in conflicting findings or claims regarding some of the conditions presented.

\section{$4 \quad$ How are VEGAs structured?}

A third debate in the literature is considered with the question: What makes VEGAs reach their goals? The literature addresses the endogenous or structural conditions that are considered to affect the implementation and outcome of VEGAs. Most of these conditions can be traced back to the literature on regulatory regimes (e.g. Scott 2001, May 2007): rules, enforcement and sanctions. In addition, the literature on VEGAs discusses reward schemes as having an impact on the performance of VEGAs (cf. Potoski and Prakash 2009). ${ }^{2}$ Table 2 provides an overview of the conditions discussed in the literature, the claims and hypotheses related to these conditions, the studies that evidence these claims and hypotheses, and finally the literature that counterclaims or provides counterevidence to these claims and hypotheses.

\section{***TABLE 2 ABOUT HERE***}

Generally, the bases of VEGAs are considered to be their rules or rule structures. Potoski and Prakash (2009, pp. 24-26) refer to these as 'club standards'; Darnall and Carmin (2005, p. 77) as 'value and goal statements' and 'plans or targets'. In short, rules are implemented to prescribe the goals of VEGAs, the expected outcomes, and participants' behaviours (cf. May 2007). The literature on VEGAs is rather limited in addressing the impact of the content and structure of rules on the actual performance of VEGAs. Notably, because VEGA administrators:

generally cannot as strongly force regulated actors to comply [as state-actors] and consequently they must rely to a greater degree on voluntary compliance, which they often seek to foster by framing regulations as involving high standards that regulated actors would want to follow because it is in their own interest to do so (Porter and Ronit 2006, p. 51).

The rules defined thus may have a strong impact on the actual performance of a VEGA. Existing regulatory literature provides some lines of reasoning: in order to be successful in achieving a VEGA's goals its rules should be adequate (Osborne and Gaebler 1992). Meaning, the goals of a VEGA should be fulfilled once its rules are met. Furthermore, its rules should be feasible participants should be able to meet the rules (Scholz 1984, Van Rooij 2006). Also, its rules should provide certainty in that they should be clear as to their meaning and how they are enforced (Bardach and Kagan 1982). A VEGA's rules should be adaptable and provide enough flexibility to deal with future or unforeseen circumstances (Bardach and Kagan 1982). Finally, the literature discusses 
the stringency of these rules (Potoski and Prakash 2009). It considers rules which are too stringent to discourage potential participants of a VEGA from joining the arrangement, but at the same time considers that rules which are too lenient do not challenge participants to really improve their environmental performance.

Where the rules of a VEGA are generally taken for granted, the monitoring or enforcement of these rules often has focal attention in the literature. Time and again, scholars find that, without monitoring or enforcement, participants do not conform to a VEGA's rules (Rivera and de Leon 2004, Darnall and Carmin 2005, Delmas and Keller 2005, Lyon and Maxwell 2007, Bailey 2008). Different types of monitoring or enforcement are discussed: self-monitoring, administrator monitoring, monitoring by a third-party hired by the participant, independent third-party monitoring, and government monitoring. It is generally considered that self-monitoring and administrator monitoring are of little avail when aiming to bring participants into compliance with a VEGA's rules (King and Lenox 2000, Darnall and Carmin 2005). More is to be expected from third-party monitoring such as certification or audits (Cashore et al. 2004, Lyon and Maxwell 2007, Darnall and Sides 2008), or governmental monitoring (DeMarzo et al. 2005, Bartle and Vass 2007). Such forms of external monitoring are expected to improve a firm's compliance with a VEGA as it may (i) cause participants to take their own or their group's obligations more seriously; (ii) stimulate the formalization of managerial commitment; (iii) reduce the possibilities of participants behaving opportunistically; and, (iv) provide a mechanism of coercion through a structure of penalties (Bansal and Hunter 2003, Cashore et al. 2004, Rivera and De Leon 2004, DeMarzo et al. 2005, Bartle and Vass 2007, Darnall and Sides 2008). Furthermore, external monitoring is easily recognized by stakeholders and may be considered as more legitimate than self-monitoring or administrator monitoring. Yet, external monitoring is not as easily accepted in each and every context (cf. OECD 2003).

The keys to monitoring or enforcement are the disciplinary measures taken when noncompliance is traced. These measures may be understood to be the third structural condition of VEGAs. The literature presents two lines of reasoning. Following common-good theorizing (e.g. Jordan 1989), a strand of literature argues that the actual rewards of participating in a VEGA should compel participants to comply (King and Lenox 2000). Yet, following deterrence theorizing (Hawkins 1984, Reiss 1984), another strand of literature argues that more severe disciplinary measures are needed and the potential penalties arising from detected violation should be feared (Lenox and Nash 2003). Different forms of penalizing are discussed: financial penalties, withdrawal of a participants' membership, or publication of the names of those in violation (King and Lenox 2000, Short and Toffel 2010).

The actual rewards or the reward scheme may be considered to be a fourth and final structural condition of VEGAs. Rewards for participants come in many forms: information (Lyon and Maxwell 2007), access to public officials (Magagna 1988, Hunold 2001, Bischop and Davis 2002), public recognition (Arora and Cason 1996, Bansal and Hunter 2003), or financial profit (Howarth et al. 2000, Croci 2005). It is here that this debate links to the previously discussed debate: why do participants develop or join a VEGA?

To conclude, as with the contextual conditions discussed, and as Table 2 illustrates, the literature on the structural conditions of VEGAs introduces many hypotheses, but not all are (yet) evidenced. Furthermore, as Table 2 also illustrates, this literature also provides a range of counterclaims to these hypotheses, resulting in conflicting findings or claims regarding some of the conditions presented. 


\section{$5 \quad$ To what extent do VEGAs achieve their goals?}

To policy makers and practitioners the most relevant debate on VEGAs may very well be the one addressing whether VEGAs achieve their goals in improving their participants' environmental performance. Scholarship discusses both positive and negative outcomes of VEGAs (Selznick 1994, Ogus 1995, Andrews 1998, Baldwin and Cave 1999, Mol et al. 2000) - as do policy reports (EEA 1997, OECD 2003, BEUC/ANEC 2006). On the one hand, these arrangements are expected to result in the institutionalization of legal norms (Stone 1975, Ashby et al. 2004); and, as a result of market and regulatory benefits, promote beyond compliance behaviour by participants (Arora and Cason 1996, Lyon and Maxwell 2000). On the other hand, they are expected to circumvent and undermine governmental regulation and legislation (Núñez 2001, Lenox and Nash 2003); and, to disguise poor environmental performance (Bartly 2003, Lyon and Maxwell 2006) by 'serv[ing] a window-dressing function that provides both market legitimacy and reduced legal liability' (Krawiec 2003, p. 487). The outcome of this fourth debate in the literature is somewhat discouraging: repeatedly studies find that participants of such mechanisms do not show better environmental performance than nonparticipants (for overviews, see Lyon and Maxwell 2007, Morgenstern and Pizer 2007, Darnall and Sides 2008) (exceptions are, Potoski and Prakash 2005, Prakash and Potoski 2006). Three potential and somewhat related causes are highlighted in the literature.

First, a major concern is the level of participants' compliance with a mechanism's rules. Various studies discuss both a lack of enforcement of such instruments and a lack of disciplining when non-compliance is found (Rivera and de Leon 2004, Darnall and Carmin 2005, Delmas and Keller 2005, Lyon and Maxwell 2007). Here the literature generally agrees that some form of thirdparty monitoring is necessary to ensure a VEGA's performance - see further the discussion of the literature above.

Second, VEGAs may attract free-riders. Some firms may be attracted to the potential rewards of a VEGA (reputation, clientele), but ultimately diminish the effects of a VEGA as their actual intentions are not to improve their environmental performance (Welch et al. 2000). At least this reasoning may provide an understanding of why a VEGA's early years' success dampens when new firms join the regime in later years (Rivera and De Leon 2004, Delmas and Keller 2005, Lyon and Maxwell 2007). A study by Arora and Cason (1996), however, counterclaims this assumption and finds no evidence of declining success rates over time.

Third, a VEGA may merely be used to 'greenwash' a firm's or a group of firms' environmental performance (Lyon and Maxwell 2006, Delmas and Montes-Sancho 2007). Greenwash may be defined as: 'the selective disclosure of positive information about a company's environmental or social performance, without full disclosure of negative information on these dimensions' (Lyon and Maxwell 2006, p. 6). Note that greenwash is not the same as poor environmental performance, or failing to report negative information. Greenwash 'involves the additional step of selectively choosing to report positive information' (Lyon and Maxwell 2006, p. 6).

Do these negative findings imply that we should fully abolish VEGAs in environmental policies? Some literature is hopeful, and presents claims as to why we should not. From a normative point of view, this literature argues that VEGAs should ultimately assist as many firms as possible to improve their environmental performance, and should not focus on ensuring that participants perform better than non-participants (cf. Lyon and Maxwell 2007). Even without an improvement in the environmental performance of participants over non-participants, VEGAs may very well have an impact. An example is the diffusion effect of the experiences with the VEGA (Lyon and Maxwell 2007): the information on the VEGA and the experiences with it will gradually diffuse among 
participants and non-participants. As a result, non-participants may implement the VEGA without actually joining it. This may result in the better environmental performance of non-participants and, related, a diminishing of the differences in environmental performance between participants and non-participants over time. The possibility of such spill-over effects from one firm (e.g. participant) to another (e.g. non-participant) have been addressed by Reid and Toffel (2009), who find that 'shareholder activism directed at a single firm can spur industry-wide changes in practices' (Reid and Toffel 2009, p. 1172). Other examples of how VEGAs can make an impact are: the testing of new methods of production; the setting of a focal point; technical assistance; the training of staff; the collection and storage of, and access to information; and the establishment of peer-networks (Lyon and Maxwell 2007, Darnall and Sides 2008).

\section{Conclusion and discussion: where next in studying VEGAs?}

Current theorizing holds that in some circumstances VEGAs are effective alternatives, supplements or complements to existing state-centred environmental legislation (Gunningham and Grabosky 1998, Cashore et al. 2004, Potoski and Prakash 2009) - though, in others they are not (Alberini and Segerson 2002, Koehler 2007, Borck and Coglianese 2009). This review article has provided insights into a range of studies on VEGAs and their findings by discussing four related debates in the literature: (i) the level of voluntarism in these arrangements and their interaction with environmental state legislation; (ii) the contextual conditions that affect the development of VEGAs and their participants' willingness to join; (iii) the structural conditions that affect the performance of VEGAs; and, (iv) the actual effectiveness of VEGAs in ensuring an increase in their participants' environmental performance.

From this review two broad conclusions may be drawn. First, the different debates all have a different focus and hence present different findings - especially as each debate logically leads to its own success criteria. In studying these debates, when to assess a VEGA as successful and when not remains unclear. First, the debate on voluntarism tends to assess a VEGA as successful if it meets or moves beyond existing environmental state legislation. Subsequently, the debate on contextual conditions tends to assess a VEGA as successful if it moves from the developmental stage into implementation and if it attracts (i) enough participants to limit the transaction costs of joining to a reasonable level, and (ii) enough consumer demand to make participation rewarding. Then, the debate on structural conditions tends to assess a VEGA as successful if its participants comply with its regulations. Finally, the debate on goal achievement tends to assess a VEGA as successful if the arrangement, overall, results in an improvement in the environmental performance of its participants over non-participants

Focusing on a single debate seems of little avail in answering the question as to whether VEGAs may truly provide effective alternatives or complements to state legislation. Scholars in the field are challenged to take a broader view in assessing VEGAs and move beyond the individual debates. A more critical stance in these debates might help us to better understand whether, when, and how VEGAs can actually make a difference in addressing the environmental challenges we face. A broader view may further provide a better understanding of how VEGAs perform in pluralistic settings of different environmental policy tools - voluntary and coerced - as is often the case in regulatory practice (e.g. Gunningham and Grabosky 1998, Holzinger et al. 2006, Hey et al. 2007).

The second major conclusion from this review is that the literature presents many claims and hypotheses on the performance of VEGAs, but limited evidence exists to support or falsify them. Also, many of the claims, hypotheses and findings presented in the literature are conflicting in 
nature - see Tables 1 and 2 . An underlying reason for the conflicting findings presented may be found in the tendency in the literature to study contextual conditions in isolation from structural conditions. If we truly want to understand whether and how VEGAs may be alternatives, supplements or complements to environmental state legislation we need to study the interaction between these contextual and structural conditions (for an excellent example of a study that does so, see Mikler 2009) - in other words: what works where, and how?

That context matters and that structure matters has become clear from earlier studies on VEGAs. Instead of re-stressing these points, future scholarship in this field may wish to comparatively study similarly structured VEGA's in different contextual settings, and differently structured VEGA's in similar contextual settings. This may provide policy makers and practitioners with the necessary insights into when and where to expect that a VEGA may be successful in improving its participants' environmental performance; it may help to gain a better understanding as to why VEGAs appear common in approach in certain institutional settings, whereas they appear less so in others (EEA 1997, OECD 2003); and it may enable sophisticated conceptualization and theory development on how VEGAs emerge, develop and cause their effects.

In reviewing the literature on VEGAs, it became clear that the bulk of the literature is composed of single VEGA, single industry, or single country studies. Comparative analyses that either follow a 'most different system design' (cf. Hopkin 2010) or a 'compound research design' (cf. Levi-Faur 2006) are in short supply. Such research designs do, however, provide for stronger arguments to generalize findings on causal links between variables than the oft applied 'most similar system' designs in contemporary VEGA studies. Future research may aim to compare VEGAs in different countries and sectors to gain a better understanding as to whether VEGAs develop and operate following a general pathway, or whether country or sector characteristics are of importance (for valuable cross-country and cross-sector studies, see Mol et al. 2000, Orts and Deketelaere 2001, Morgenstern and Pizer 2007).

Furthermore, current literature falls short in combining qualitative and quantitative data. The majority of literature cited is either based on qualitative or quantitative data. As such, future studies on VEGAs may be based on mixed-method research designs. This would allow either the testing of findings from qualitative data and generate more robust generalizations; or, would provide a richer understanding of generalizations derived from quantitative data by providing an indepth insight into the causal relationships traced (cf. Hopkin 2010).

In summary, existing literature has made an important contribution to our understanding of VEGAs, and how contextual and structural conditions may affect their performance. Despite these insights into the strengths and limitations of VEGAs, the literature remains relatively undiscerning in terms of specifying (i) whether or not VEGAs make effective alternatives or complements to environmental legislation in addressing contemporary environmental risks; and (ii) which combinations of conditions are most crucial in raising the performance of VEGAs.

\section{Endnotes}

* The author wishes to thank Neil Gunningham, Peter May, Aseem Prakash, and Benjamin Cashore for reviewing and discussing earlier drafts of this article. He further thanks the participants and audience of the LSA2011 Annual Meeting's panel on Voluntary Regulatory Regimes for helpful comments and discussion on an earlier draft of this article. 
1. Another way of addressing such developments is to look at the function of a VEGA in relation to existing legislation (Ten Brink, 2002): VEGAs may have a 'bridging function' towards existing legislation; a 'support function' to help the implementation of legal requirements; or, an 'independent function' when there is no direct relation between the VEGA and existing legislation.

2. Other classifications exist. Darnall and Carmin (2005), for instance, use a slightly different terminology by discussing mission requirements, administrative requirements, and conformance requirements. Mission requirements relate to the expression of value and goal statements, the development of plans and targets to reach these goals, and a management plan to steer the process of reaching these goals. Administrative requirements relate to the requirements on documentation that are needed for communication on and transparency of participants' behaviour. Conformance requirements relate to monitoring, rewarding and disciplining. 
Tables - Table 1 Contextual conditions

\begin{tabular}{|c|c|c|c|}
\hline $\begin{array}{l}\text { Contextual } \\
\text { condition }\end{array}$ & Claim/hypothesis & Evidenced & $\begin{array}{l}\text { Counterclaims } \\
\text { /counterevidence }\end{array}$ \\
\hline \multirow[t]{2}{*}{$\begin{array}{l}\text { Current or future } \\
\text { state legislation or } \\
\text { regulation }\end{array}$} & $\begin{array}{l}\text { Non-state actors engage in the development of or participate in VEGAs to prevent } \\
\text { implementation of additional or future governmental regulation. } \\
\text { (Young 1994, Scott 2001, 2002, MacDonald and Richardson 2004, Schulz and Held } \\
\text { 2004, Bernstein and Hannah 2008, Thatcher and Coen 2008, Dibden and Cocklin } \\
\text { 2010, Green 2010) }\end{array}$ & $\begin{array}{l}\text { (Maxwell et al. 2000, } \\
\text { Khanna and Anton } \\
\text { 2002, Rivera and De } \\
\text { Leon 2004, Reid and } \\
\text { Toffel 2009) }\end{array}$ & (Welch et al. 2000) \\
\hline & $\begin{array}{l}\text { State actors engage in the development of or participate in VEGAs to limit public } \\
\text { policy costs. } \\
\text { (Esty and Chertow 1997, Darnall and Carmin 2005, Short and Toffel 2010, Segerson } \\
\text { and Miceli 1998, Delmas and Terlaak 2001, Bartly 2003, Darnall and Carmin 2005) }\end{array}$ & $\begin{array}{l}\text { (Lyon and Maxwell } \\
\text { 2007) }\end{array}$ & \\
\hline \multirow[t]{4}{*}{ Market conditions } & $\begin{array}{l}\text { Non-state actors engage in the development of or participate in VEGAs when the } \\
\text { cost of doing so outweighs the cost of not doing so. } \\
\text { (Howarth et al. 2000, Croci 2005) }\end{array}$ & $\begin{array}{l}\text { (Porter and Van der } \\
\text { Linde 1995, Arora and } \\
\text { Cason 1996, Khanna } \\
\text { and Zilberman 1997, } \\
\text { Altman 2001, Delmas } \\
\text { and Terlaak 2001) }\end{array}$ & $\begin{array}{l}\text { (Bagnoli and Watts } \\
\text { 2003, Bartly 2003, p. } \\
\text { 435) }\end{array}$ \\
\hline & $\begin{array}{l}\text { Non-state actors engage in the development of or participate in VEGAs in response } \\
\text { to consumers' demands for better environmental performance - 'green } \\
\text { consumerism'. } \\
\text { (Arora and Gangopadhyay 1995, Feddersen and Gilligan 2001, Florida and Davison } \\
2001, \text { Heyes and Maxwell 2004, Baron and Diermeier 2007) }\end{array}$ & $\begin{array}{l}\text { (Cairncross 1992, } \\
\text { Arora and Cason 1995, } \\
\text { 1996, Khanna and } \\
\text { Damon 1999, Khanna } \\
\text { and Anton 2002) }\end{array}$ & $\begin{array}{l}\text { (Darnall and Carmin } \\
\text { 2005) }\end{array}$ \\
\hline & $\begin{array}{l}\text { Non-state actors engage in the development of or participate in VEGAs in response } \\
\text { to investors' demands for better environmental performance - 'green investors'. } \\
\text { (Hoffman 2001, Khanna and Anton 2002, Graff Zivin and Small 2005) }\end{array}$ & $\begin{array}{l}\text { (Hamilton 1995, } \\
\text { Khanna et al. 1998) }\end{array}$ & \\
\hline & $\begin{array}{l}\text { Non-state actors engage in the development of VEGAs to hinder their industry } \\
\text { competitors. } \\
\text { (Barrett 1991, Salop and Scheffman 1991, Welch et al. 2000) }\end{array}$ & & \\
\hline
\end{tabular}




\begin{tabular}{|c|c|c|c|}
\hline \multirow[t]{2}{*}{ Societal pressures } & $\begin{array}{l}\text { State or non-state actors engage in the development of or participate in VEGAs in } \\
\text { response to NGOs' demands for better environmental performance. } \\
\text { (Jenkins 1983, Arora and Cason 1996, Hoffman 1999, King and Lenox 2000, Khanna } \\
\text { and Anton 2002, Bartly 2003, Rivera and De Leon 2004, Baron and Diermeier 2007, } \\
\text { Den Hond and De Bakker 2007, King 2008, Mayer and Gereffi 2010) }\end{array}$ & $\begin{array}{l}\text { (Bartly 2003, Reid and } \\
\text { Toffel 2009) }\end{array}$ & \\
\hline & $\begin{array}{l}\text { Non-state actors engage in the development of or participate in VEGAs in response } \\
\text { to their employees' demands for better environmental performance- 'green } \\
\text { workers'. } \\
\text { (Lyon and Maxwell 2007, Brekke and Nyborg 2008, Briscoe and Safford 2008) }\end{array}$ & (Bartly 2003) & \\
\hline \multirow[t]{6}{*}{$\begin{array}{l}\text { Firm and industry } \\
\text { characteristics }\end{array}$} & $\begin{array}{l}\text { Innovative industries are more likely to develop VEGAs than non-innovative } \\
\text { industries. } \\
\text { (King and Lenox 2000, Welch et al. 2000, Khanna and Anton 2002, Weber and } \\
\text { Hemmelskamp 2005) }\end{array}$ & $\begin{array}{l}\text { (Arora and Cason } \\
1996)\end{array}$ & $\begin{array}{l}\text { (Videras and Alberini } \\
\text { 2000) }\end{array}$ \\
\hline & $\begin{array}{l}\text { Industries with strong internal competition are more likely to develop VEGAs than } \\
\text { industries with less strong or no internal competition. } \\
\text { (Arora and Cason 1996, Khanna and Anton 2002, Rivera and De Leon 2004, Weber } \\
\text { and Hemmelskamp 2005) }\end{array}$ & $\begin{array}{l}\text { (Porter and Ronit } \\
\text { 2006) }\end{array}$ & \\
\hline & $\begin{array}{l}\text { Firms with an international orientation are more likely to develop or participate in } \\
\text { VEGAs than firms with a non-international orientation. } \\
\text { (Bansal and Hunter 2003) }\end{array}$ & & \\
\hline & $\begin{array}{l}\text { Firms with a high organizational capability are more likely to develop or participate } \\
\text { in VEGAs than firms with a low organizational capability. } \\
\text { (Olson 1965, Rees 1988, Parker 2002, Baarsma et al. 2003, Potoski and Prakash } \\
\text { 2009) }\end{array}$ & (Wilson 2004) & \\
\hline & $\begin{array}{l}\text { Firms are more likely to participate in VEGAs when these set low entry barriers. } \\
\text { (Arora and Cason 1996, Darnall and Carmin 2005, Short and Toffel 2010) }\end{array}$ & & \\
\hline & $\begin{array}{l}\text { Firms with a strong past environmental performance are most likely to participate in } \\
\text { VEGAs than firms with a poor past environmental performance. } \\
\text { (Bansal and Hunter 2003) }\end{array}$ & (King and Lenox 2000) & $\begin{array}{l}\text { (Welch et al. 2000, } \\
\text { Rivera and De Leon } \\
\text { 2004, Delmas and } \\
\text { Keller 2005, Lyon and } \\
\text { Maxwell 2007) }\end{array}$ \\
\hline
\end{tabular}


Tables - Table 2: Structural conditions

\begin{tabular}{|c|c|c|c|}
\hline Structural condition & Claim/hypothesis & Evidenced & $\begin{array}{l}\text { Counter } \\
\text { claims/evidence }\end{array}$ \\
\hline \multirow[t]{5}{*}{ Rules } & $\begin{array}{l}\text { VEGAs' rules should be adequate - i.e. when complied with, this should result in } \\
\text { goal achievement. } \\
\text { (cf. Osborne and Gaebler 1992, Porter and Ronit 2006) }\end{array}$ & & \\
\hline & $\begin{array}{l}\text { VEGAs' rules should be feasible - i.e. participants should be able to meet these } \\
\text { rules. } \\
\text { (Greer and Downey 1981, Scholz 1984, Van Rooij 2006, cf. Darnall and Sides } \\
2008 \text { ) }\end{array}$ & & \\
\hline & $\begin{array}{l}\text { VEGAs' rules should provide certainty - i.e. there is little misunderstanding of } \\
\text { the meaning of the rules. } \\
\text { (cf. Bardach and Kagan 1982, Van der Heijden 2009) }\end{array}$ & & \\
\hline & $\begin{array}{l}\text { VEGAs' rules should be adaptable - i.e. be flexible to deal with unforeseen } \\
\text { circumstances. } \\
\text { (cf. Bardach and Kagan 1982, Van Rooij 2006) }\end{array}$ & & \\
\hline & $\begin{array}{l}\text { Stringent rules generate credibility. } \\
\text { (Potoski and Prakash 2009) }\end{array}$ & & \\
\hline \multirow[t]{3}{*}{$\begin{array}{l}\text { Monitoring and } \\
\text { enforcement }\end{array}$} & Without enforcement participants will not comply with VEGAs' rules. & $\begin{array}{l}\text { (Rivera and De Leon } \\
\text { 2004, Darnall and } \\
\text { Carmin 2005, Delmas } \\
\text { and Keller 2005, Lyon } \\
\text { and Maxwell 2007, } \\
\text { Bailey 2008) }\end{array}$ & \\
\hline & $\begin{array}{l}\text { Self-enforcement by VEGAs' participants does not result in compliance by } \\
\text { VEGAs' participants. } \\
\text { (King and Lenox 2000) }\end{array}$ & & \\
\hline & $\begin{array}{l}\text { Third-party or government monitoring positively influence compliant behaviour } \\
\text { by VEGAs' participants. } \\
\text { (Núñez 2001, Cashore et al. 2004, DeMarzo et al. 2005, Bartle and Vass 2007, } \\
\text { Lyon and Maxwell 2007) }\end{array}$ & $\begin{array}{l}\text { (Potoski and Prakash } \\
\text { 2004, 2005, Darnall } \\
\text { and Sides 2008) }\end{array}$ & \\
\hline
\end{tabular}


Tables - Table 2: Structural conditions - CONTINUED

\begin{tabular}{|l|l|l|}
\hline $\begin{array}{l}\text { Disciplining non- } \\
\text { compliance }\end{array}$ & $\begin{array}{l}\text { Sanctioning when non-compliance is found positively influences compliant } \\
\text { behaviour by VEGAs' participants. } \\
\text { (Lenox and Nash 2003, Darnall and Carmin 2005) }\end{array}$ & $\begin{array}{l}\text { (King and Lenox 2000, } \\
\text { Short and Toffel 2010) }\end{array}$ \\
\hline Reward scheme & $\begin{array}{l}\text { Participants join VEGAs to obtain information on improving their environmental } \\
\text { performance. } \\
\text { (Bansal and Hunter 2003, Lyon and Maxwell 2007) }\end{array}$ & $\begin{array}{l}\text { Participants join VEGAs to develop close relationships with and influence state- } \\
\text { regulators. } \\
\text { (Magagna 1988, Hunold 2001, Bischop and Davis 2002, Baranzini and Thalmann } \\
\text { 2004) }\end{array}$ \\
\hline & $\begin{array}{l}\text { Participants join VEGAs to gain public recognition. } \\
\text { (Arora and Cason 1996, Bansal and Hunter 2003) }\end{array}$ & \\
\hline $\begin{array}{l}\text { Participants join VEGAs because it is financially profitable to do so. } \\
\text { (Howarth et al. 2000, Croci 2005) }\end{array}$ & \\
\hline
\end{tabular}


Van der Heijden (2013) Voluntary environmental governance arrangements - page 15 of 17

\section{References}

Alberini, A. and Segerson, K., 2002. Assessing voluntary programs to improve environmental quality. Environmental and Resource Economics, 22 (1-2), 157-184.

Altman, M., 2001. When green isn't mean. Ecological Economics, 36 (1), 31-44.

Andrews, R.N.L., 1998. Environmental regulation and business self-regulation. Policy Science, 31 (3), 177-197.

Ansell, C. and Gash, A., 2008. Collaborative governance in theory and practice. JPART, 18 (4), 543571.

Armstrong, K. and Kilpatrick, C., 2007. Law, governance, or new governance? Columbia Journal of European Law, 13 (3), 649-678.

Arora, S. and Cason, T.N., 1995. An experiment in voluntary environmental regulation: Participation in epa's 33-50 program. Journal of Environmental Economics and Management, 28 (3), 271286.

Arora, S. and Cason, T.N., 1996. Why do firms volunteer to exceed environmental regulations? Land Economics, 72 (4), 413-432.

Arora, S. and Gangopadhyay, S., 1995. Toward a theoretical model of voluntary overcompliance. Journal of Economic Behavior and Organization, 28 (3), 289-309.

Ashby, S., Chuah, S.-H., and Hoffmann, R., 2004. Industry self-regulation. International Journal of the Economics of Business, 11 (1), 91-106.

Baarsma, B. et al., 2003. Do it yourself? Stock-taking study of self-regulation instruments. Amsterdam: SEO.

Bagnoli, M. and Watts, S.G., 2003. Selling to socially responsible consumers. JEMS, 12 (3), 419-445. Bailey, I., 2008. Industry environmental agreements and climate policy. JEPP, 10 (2), 153-173.

Baldwin, R. and Cave, M., 1999. Understanding regulation. New York: Oxford University Press.

Bansal, P. and Hunter, T., 2003. Strategic explanations for the early adoption of iso 14001. Journal of Business Ethics, 46 (3), 289-299.

Baranzini, A. and Thalmann, P., 2004. Voluntary approaches in climate policy. Cheltenham: Edward Elgar Pub.

Bardach, E. and Kagan, R.A., 1982. Going by the book. Philadelphia: Temple University Press.

Baron, D.P. and Diermeier, D., 2007. Strategic activism and nonmarket strategy. Journal of Economics and Management Strategy, 16, 599-634.

Barrett, S., 1991. Environmental regulation for competitive advantage. Business Strategy Review, 2 (1), 1-15.

Bartle, I. and Vass, P., 2007. Self-regulation within the regulatory state. Public Administration, 85 (4), 885-905.

Bartly, T., 2003. Certifying forests and factories. Politics \& Society, 31 (3), 433-464.

Bernstein, S. and Hannah, E., 2008. Non-state global standard setting and the WTO. Journal of International Economic Law, 11 (3), 575-608.

BEUC/ANEC, 2006. Voluntary environmental agreements. Brussels: BEUC/ANEC.

Bischop, P. and Davis, G., 2002. Mapping public participation in policy choices. AJPA, 61 (1), 14-29.

Borck, J.C. and Coglianese, C., 2009. Voluntary environmental programs. Annual Review of Environmental Resources, 34, 305-324.

Brekke, K.A. and Nyborg, K., 2008. Attracting responsible employees: Green production as labor market screening. Resource and Energy Economics, 30 (4), 509-526.

Bressers, H.et al., 2011. Negotiation-based policy instruments and performance. Journal of Public 
Van der Heijden (2013) Voluntary environmental governance arrangements - page 16 of 17

Policy, 31 (2), 187-208.

Briscoe, F. and Safford, S., 2008. The Nixon-in-China effect. Administrative Science Quarterly., 53 (3), 460-491.

Cafaggi, F. and Janczuk, A., 2010. Private regulation and legal integration: The European example. Business and Politics, 12 (3), 1-40.

Cairncross, F., 1992. Costing the Earth. Boston: Harvard Business School Press.

Cashore, B., Auld, G., and Newsom, D., 2004. Governing through markets. New Haven: Yale University Press.

Cooper, I.and Symes, M. eds. 2009. Sustainable urban development. Volume 4. London: Routledge.

Croci, E., 2005. The handbook of environmental voluntary agreements. Dordrecht: Springer.

Darnall, N. and Carmin, J., 2005. Greener and cleaner? Policy Sciences, 38 (2-3), 71-90.

Darnall, N. and Sides, S., 2008. Assessing the performance of voluntary environmental programs. PSJ, $36(1), 95-117$.

De Bruijn, T. and Norberg-Bohm, V., 2005. Industrial transformation. Cambridge, MA: MIT Press.

De Búrca, G. and Scott, J., 2005. New governance and constitutionalism in Europe and the US. Oxford: Hart.

De Clercq, M., 2002. Negotiating environmental agreements in Europe. Cheltenham: Edward Elgar.

Delmas, M.A. and Keller, A., 2005. Free riding in voluntary environmental programs. Policy Sciences, 38 (2), 91-106.

Delmas, M.A. and Montes-Sancho, M.J., 2007. Voluntary agreements to improve environmental quality. Santa Barbara: University of California.

Delmas, M.A. and Terlaak, A.K., 2001. A framework for analyzing environmental voluntary agreements. California Management Review, 43 (3), 44-62.

DeMarzo, P.M., Fishman, M.J., and Hagerty, K.M., 2005. Self-regulation and government oversight. The Review of Economic Studies, 72 (3), 687-706.

Den Hond, F. and De Bakker, F.G.A., 2007. Ideologically motivated activism. Academy of Management Review, 32 (3), 901-924.

Dibden, J. and Cocklin, C., 2010. Re-mapping regulatory space. Geoforum, 41 (3), 410-422.

EEA, 1997. Environmental agreements: Environmental effectiveness. Luxembourg: European Environmental Agency.

Esty, D.C. and Chertow, M.R., 1997. Thinking ecologically. In Chertow, M.R. and Esty, D.C. eds. Thinking ecologically. New Haven: Yale University Press.

Feddersen, T.J. and Gilligan, T.J., 2001. Saint and markets. JEMS, 10 (1), 149-71.

Florida, R. and Davison, D., 2001. Why do firms adopt advanced environmental practices (and do they make a difference)? In Coglianese, C. and Nash, J. eds. Going private Washington: Resources for the Future.

Freeman, J., 1997. Collaborative governance in the administrative state. UCLA Law Review, 45 (1), 198.

Graff Zivin, J. and Small, A., 2005. A Modigliani-Miller theory of altruistic corporate social responsibility. Topics in Economic Analysis and Policy, 5 (1), 1-19.

Green, J.F., 2010. Private standards in the climate regime:. Business and Politics, 12 (3), 1-37.

Greer, C.R. and Downey, H.K., 1981. Industrial compliance with social legislation Stillwater: Oklahoma State University.

Gunningham, N. and Grabosky, P., 1998. Smart regulation. Oxford: Oxford University Press.

Hamilton, J.T., 1995. Pollution as news. Journal of Environmental Economics and Management, 28 
Van der Heijden (2013) Voluntary environmental governance arrangements - page 17 of 17

(1), 98-113.

Hawkins, K., 1984. Environment and enforcement regulation and the social definition of pollution.

Oxford: Oxford University Press.

Hey, C., Jacob, K., and Volkery, A., 2007. Better regulation by new governance hybrids? Journal of Cleaner Production, 15 (18), 1859-1874.

Heyes, A.G. and Maxwell, J.W., 2004. Private vs. public regulation. Journal of Environmental Economics and Management, 48 (2), 978-96.

Hoffman, A.J., 1999. Institutional evolution and change. Academy of Management Journal, 42 (4), 351-371.

Hoffman, A.J., 2001. From heresy to dogma. Stanford: Stanford Business Books.

Holzinger, K., Knill, C., and Schäfer, A., 2006. Rhetoric or reality? European Law Journal, 12 (3), 403420.

Hopkin, J., 2010. The comparative method. In Marsh, D. and Stoker, G. eds. Theory and methods in political science. New York: Palgrave, 285-307.

Howarth, R.B., Hadda, B.M., and Paton, B., 2000. The economics of energy efficiency. Energy Policy, $28(6-7), 477-486$.

Hunold, C., 2001. Corporatism, pluralism, and democracy. Governance, 14 (2), 151-167.

Jenkins, J.C., 1983. Resource mobilization theory and the study of social movements. Annual Review of Sociology, 9, 527-553.

Jordan, A., Wurzel, R. and Zito, A., 2005. The rise of new policy instruments in comparative perspective. Political Studies, 53 (3), 477-496.

Jordan, B., 1989. The Common Good. Oxford: Blackwell.

Khanna, M. and Anton, W.R.Q., 2002. Corporate environmental management. Land Economics, 78 (4), 539-558.

Khanna, M. and Damon, L., 1999. EPA's voluntary 33-50 program. Journal of Environmental Economics and Management, 37 (1), 1-25.

Khanna, M., Quimio, W., and Bojilova, D., 1998. Toxics release information. Journal of Environmental Economics and Management, 36 (3), 243-266.

Khanna, M. and Zilberman, D., 1997. Incentives, precision technology and environmental protection. Ecological Economics, 23 (1), 25-43.

King, A.A. and Lenox, M.J., 2000. Industry self-regulation without sanctions. Academy of Management Journal, 43 (4), 698-716.

King, B.G., 2008. A political mediation model of corporate response to social movement activism. Administrative Science Quarterly., 53 (3), 395-421.

Koehler, D.A., 2007. The effectiveness of voluntary environmental programs. PSJ, 35 (4), 689-722.

Krawiec, K.D., 2003. Cosmetic compliance and the failure of negotiated governance. Washington University Law Quarterly, 81, 487-544.

Lenox, M.J. and Nash, J., 2003. Industry self-regulation and adverse selection. Bussiness Strategy and the Environment, 12 (6), 343-356.

Levi-Faur, D., 2006. Varieties of regulatory capitalism. Governance, 19 (3), 367-382.

Lyon, T.P. and Maxwell, J.W., 2000. Voluntary approaches to environmental regulation. In Franzini, M. and Nicita, A. eds. Economic institutions and environmental policy. Aldershot, UK: Ashgate, 142-174.

Lyon, T.P. and Maxwell, J.W., 2006. Greenwash. Ann Arbor: Ross School of Business.

Lyon, T.P. and Maxwell, J.W., 2007. Environmental public voluntary programs reconsidered. The 
Van der Heijden (2013) Voluntary environmental governance arrangements - page 18 of 17

Policy Studies Journal, 35 (4), 723-750.

Macdonald, L.D. and Richardson, A.J., 2004. Identity, appropriateness and the construction of regulatory space. Accounting, Organizations and Society, 29 (5), 489-524.

Magagna, V.V., 1988. Representing efficiency. The Review of Politics, 50 (3), 420-444.

Maxwell, J.W., Lyon, T.P., and Hackett, S.C., 2000. Self-regulation and social welfare. Journal of Law and Economics, 43 (October), 583-618.

May, P.J., 2007. Regulatory regimes and accountability. Regulation \& Governance, 1 (1), 8-26.

Mayer, F. and Gereffi, G., 2010. Regulation and economic globalization. Business and Politics, 12 (3), $1-25$.

Mikler, J., 2009. Greening the car industry. Cheltenham: Edward Elgar.

Mol, A., Volkmar, L., and Liefferink, D., 2000. The voluntary approach to environmental policy: Joint environmental policy making in Europe. Oxford: Oxford University Press.

Morgenstern, R. and Pizer, W., 2007. Reality check: The nature and performance of voluntary environmental programs in the United States, Europe and Japan Washington: RFF Press.

Mueller, D.C., 2003. Public choice III. Cambridge: Cambridge University Press.

Nash, J. and Ehrenfeld, J., 1997. Codes of environmental management practice. Annual Review of Energy and the Environment, 22, 487-535.

Nel, J.G. and Wessels, J.-A., 2010. How to use voluntary, self-regulatory and alternative environmental compliance tools. Potchefstroom Electronic Law Journal, 13 (5), 48-78.

Núñez, J., 2001. A model of self-regulation. Economic Letters, 74, 91-97.

OECD, 2003. Voluntary approaches for environmental policy. Paris: OECD.

Ogus, A., 1995. Rethinking self-regulation. Oxford Journal of Legal Studies, 15 (1), 97-108.

Olson, M., 1965. The logic of collective action. Cambridge, MA: Harvard University Press.

Orts, E. and Deketelaere, K., 2001. Environmental contracts. London: Kluwer Law International.

Osborne, D. and Gaebler, T., 1992. Reinventing government. Reading: Addison-Wesley Publishers.

Parker, C., 2002. The open corporation. Cambridge: Cambridge University Press.

Porter, M. and Van der Linde, C., 1995. Toward a new conception of the environmentcompetitiveness relationship. Journal of Economic Perspectives, 9 (4), 97-118.

Porter, T. and Ronit, K., 2006. Self-regulation as policy process. Policy Sciences, 39 (1), 41-72.

Potoski, M. and Prakash, A., 2004. The regulatory dilemma. PAR, 64 (3), 152-163.

Potoski, M. and Prakash, A., 2005. Covenants with weak swords. JPAM, 24 (4), 745-769.

Potoski, M. and Prakash, A., 2009. Voluntary programs. Cambridge: MIT Press.

Prakash, A. and Potoski, M., 2006. Racing to the bottom? American Journal of Political Science, 50 (2), 350-364.

Rees, J.V., 1988. Reforming the workplace. Philadelphia: University of Pennsylvania Press.

Reid, E.M. and Toffel, M.W., 2009. Responding to public and private politics. Strategic Management Journal, 30 (11), 1157-1178.

Reiss, A., 1984. Selecting strategies of social control over organizational life. In Hawkins, K. and Thomas, J.M. eds. Enforcing regulation. Boston: Kluwer-Nijhoff, 23-35.

Rivera, J. and De Leon, P., 2004. Is greener whiter? The Policy Studies Journal, 32 (3), 417-437.

Salop, S.C. and Scheffman, D.T., 1991. Raising rivals' costs. The American Economic Review, 73 (2), 267-271.

Scholz, J.T., 1984. Voluntary compliance and regulatory enforcement. Law \& Policy, 6 (4), 385-404.

Schulz, W. and Held, T., 2004. Regulated self-regulation as a form of modern government Eastleigh: University of Luton Press. 
Scott, C., 2001. Analyzing regulatory space. Public Law, 2001, 283-305.

Scott, C., 2002. Private regulation of the public sector. Journal of Law and Society, 29 (1), 56-76.

Segerson, K. and Miceli, T., 1998. Voluntary environmental agreements. Journal of Environmental Economics and Management, 36 (2), 109-130.

Selznick, P., 1994. The moral commonwealth. Berkeley: University of California Press.

Short, J. and Toffel, M.W., 2010. Making self-regulation more than merely symbolic. Administrative Science Quarterly, 55 (2), 361-396.

Stone, C.D., 1975. Where the law ends. New York: Harper \& Row.

Thatcher, M. and Coen, D., 2008. ReshapingEuropean regulatory space. West European Politics, 31 (4), 806-836.

Trubek, D. and Trubek, L., 2007a. Narrowing the gap? Law and new approaches to governance in the European Union. The Columbia Journal of European Law., 13 (3), 539-564.

Trubek, D. and Trubek, L., 2007b. New governance \& legal regulation. Columbia Journal of European Law, 13 (3), 539-564.

Van der Heijden, J., 2009. Building regulatory enforcement regimes. Amsterdam: IOS Press.

Van der Heijden, J., 2010. A short history of studying incremental institutional change. Regulation \& Governance, 4 (2), 230-243.

Van der Heijden, J., 2011. Friends, enemies or strangers? Law \& Policy, 33 (3), 367-390.

Van Rooij, B., 2006. Regulating land and pollution in China. Leiden: University of Leiden.

Videras, J. and Alberini, A., 2000. The appeal of voluntary environmental programs. Contemporary Economic Policy, 18 (4), 449-461.

Weber, M. and Hemmelskamp, J., 2005. Towards environmental innovation systems. Berlin: Springer. Welch, E., Mazur, A., and Bretschneider, S., 2000. Voluntary behavior by electric utilities. JPAM, 19 (3), 407-425.

Wilson, G., 2004. The Australian 'landcare' movement: Towards 'post-productivist'" rural governance? Journal of Rural Studies, 20 (4), 461-484.

Young, J., 1994. Outlining regulatory space. Accounting Organisations and Society, 19 (1), 83-109.

Young, O. ed. 1999. The effectiveness of international environmental regimes. Cambridge, MA: MIT Press. 